Semina $\square \quad \mathrm{Nr} 14$

Scientiarum 2015

s. $130-134$

DOI: http://dx.doi.org/10.15633/ss. 1083

\title{
Teologia kontra nauka, czyli skąd wziął się świat?
}

Michał Heller, Tadeusz Pabjan, Stworzenie i poczatek wszechświata, Copernicus Center Press, Kraków 2013, ss. 177

Czy ewolucja i darwinizm wykluczaja stworzenie człowieka przez Boga? Jeśli tak, to jak należy rozumieć biblijny opis stworzenia? Już na wstępie mojej recenzji zamieszczam te - jakże znaczace ze współczesnego punktu widzenia - pytania, które wprowadza sporo zamętu w ludzkim pojmowaniu poczattków świata.

Na okładce książki Stworzenie i poczatek wszechświata pojawia się dość kłopotliwe zdanie, wymagające zajęcia indywidualnego stanowiska: „Jak pogodzić wiarę w stworzenie świata przez Boga z wiedzą naukową?". To dość trudne zestawienie treści teologicznych i filozoficznych czyni to dzieło niezwykle interesujacym dla osób zastanawiających się nad własnym istnieniem. Rzetelność odniesienia się autorów do tej problematyki skłoniła mnie do wyboru właśnie tej pozycji.

Ksiądz profesor Michał Heller jest wybitnym w swojej dziedzinie kosmologiem, teologiem i filozofem. Jako wieloletni profesor i wykładowca Uniwersytetu Papieskiego Jana Pawła II w Krakowie zna podstawowe problemy i trudności z pogranicza teologii i nauki, z jakimi borykaja się przede wszystkim studenci teologii. Jest laureatem licznych nagród i wyróżnień związanych ze szczególnymi osiągnięciami w dziedzinie kosmologii, fizyki, filozofii i teologii.

Współautorem ksiązki Stworzenie i poczatek wszechświata jest ks. dr hab. Tadeusz Pabjan - kierownik Katedry Filozofii na Wydziale Teologicznym Uniwersytetu Papieskiego Jana Pawła II 
w Krakowie Sekcja w Tarnowie. Jest on także członkiem Ośrodka Badań Interdyscyplinarnych przy UPJPII w Krakowie.

W zamieszczonym wstępie autorzy wskazuja, iz:

Niniejsza książka powstała na swego rodzaju społeczne zamówienie. Katecheci uczacy w szkołach religii niejednokrotnie zwracali się do nas z prośbą o wskazanie materiałów, które ułatwiłyby im przekazywanie swoim uczniom trudnej, ale niezwykle ważnej prawdy o stworzeniu świata przez Boga ${ }^{1}$.

Książka ta składa się z sześciu rozdziałów. Autorzy próbuja w swoim dziele wprowadzić czytelnika w świat Biblii oraz nauki. Obrazem tej działalności jest cały pierwszy rozdział omawiający Księgę Rodzaju. Już na początku rozważań pojawia się niezwykle wyraźne zastrzeżenie: Pismo Święte nie jest źródłem wiedzy historycznej, naukowej. Nie można go zatem odczytywać dosłownie. Jest bowiem poematem, którego głównym zadaniem jest ukazanie boskiej działalności w świecie. Istotne są także wskazówki, jak należy właściwie odczytywać to, co zostało zawarte w Księdze Rodzaju. Niewłaściwe wydaje się tutaj nakładanie na tekst biblijny współczesnych doświadczeń człowieka. Są one bowiem uwarunkowane przeżyciami, nowymi pojęciami, a także o wiele dalej posuniętym rozwojem wiedzy niż ten, który posiadali autorzy natchnieni. Hebrajczycy nie szukali odpowiedzi na pytanie: skąd wziął się świat, ale bardziej zależało im na ukazaniu obecności Boga wśród narodu ybranego przebywajaccego na wygnaniu.

Kolejny rozdział, Teologia stworzenia, skłania czytelnika do refleksji: skoro w Starym Testamencie Żydzi nie interesowali się problematyka stworzenia, skąd ta nagła fascynacja tym tematem w Nowym Testamencie? Autorzy próbują odpowiedzieć na to pytanie, wskazując, że przez podróże apostolskie uczniowie Chrystusa poznali filozofię grecką (przede wszystkim Paweł), co skłoniło ich do rozważań na ten temat. Sama kwestia odkupienia, rzutują-

1 M. Heller, T. Pabjan, Stworzenie i poczatek wszechświata, Kraków 2013, s. 7. 
ca na całą historię ludzkości, skłoniła interpretatorów, by powrócić do Raju.

Teologiczne przesłanie o Stworzeniu, które rozpoczyna długą historię zbawienia, prowadząca do Wcielenia i Odkupienia, można odczytać z wielu różnych miejsc Nowego Testamentu, ale szczególnie wyraźnie przesłanie to pobrzmiewa w Prologu Ewangelii św. Jana. Otwierajace go słowa „na początku” mają identyczne brzmienie jak pierwsze słowa Heksaemeronu i podobieństwo to na pewno nie jest przypadkowe ${ }^{2}$.

Rozdział trzeci, Stworzenie a odwieczność świata, jest według mnie najbardziej kluczowym zbiorem refleksji. Autorzy wskazują bowiem, jak wielkim zagrożeniem dla teologii europejskiej doby św. Augustyna była zbyt wielka fascynacja platonizmem. Pytano przede wszystkim o to, czy świat jest odwieczny, czy może czasowy. Dużymi osiagnięciami w tej kwestii wykazał się św. Tomasz, który wnikliwie analizując pojęcia czasu i wieczności, zakończył zbędne dywagacje na temat tego, co Bóg robił zanim stworzył nasz świat. Uważam, że niezwykle istotne jest zwrócenie uwagi przez autorów na fakt, iź świat jest stwarzany przez Boga nieustannie w konkretnym czasie.

Czwarty i piąty rozdział niniejszej książki mają charakter porównania. Sa one bowiem - jak stwierdzaja sami autorzy - konfrontacja teologicznej koncepcji stworzenia $\mathrm{z}$ dwoma istotnymi aspektami współczesnego, naukowego obrazu świata ${ }^{3}$. Pojawia się tutaj - odbijająca się szerokim echem we współczesnym świecie - koncepcja Wielkiego Wybuchu. Czy jednak nie burzy ona światopoglądu zwykłego, pobożnego katolika widzącego swoje stworzenie w szóstym dniu działalności Pana Boga?

Otóż Pius XII utożsamiał Wielki Wybuch z biblijnym aktem stworzenia. Jednak w XX wieku stwierdzono, iż nie można „zapychać" Bogiem każdej dziury w dowodzeniu naukowym (nauka bowiem jest w stanie zbadać historię wszechświata „tylko” do 13,8 mld

M. Heller, T. Pabjan, Stworzenie i poczqtek wszechświata, dz. cyt., s. 48.

3 M. Heller, T. Pabjan, Stworzenie i poczatek wszechświata, dz. cyt., s. 10. 
lat wstecz). Autorzy opisują także fakt, iż Newton wierzył i wyznawał w Bogu kosmicznego „zegarmistrza”, który „nakręcił” świat i pozostawił go człowiekowi. Moim zdaniem ta kwestia nie do końca została w sposób jednoznaczny wytłumaczona, gdyż to nie Newton był jej pomysłodawca, ale Leibniz ${ }^{4}$. Ten wybitny fizyk odrzucał bowiem mechaniczne pojmowanie świata. Koncepcja zegarmistrza została jednak „wciśnięta” w myśl Newtona ze względu na to, iż jego teksty zostały opublikowane po jego śmierci. Uległy one dość swobodnej interpretacji.

Częstym zarzutem wobec osób wierzących jest to, iż odrzucaja oni w pełni ewolucję. Gdyby tak było, wiązałoby się to z bezkrytycznym przyjmowaniem wszystkiego, co znajduje się na kartach Pisma Świętego. Pytanie postawione przeze mnie na początku recenzji jest błędne: nie można przeciwstawiać ewolucjonizmu opisowi stworzenia zawartemu w Księdze Rodzaju. Przykre jest jednak to, że nie wszyscy chrześcijanie to dostrzegaja. Warto wspomnieć tutaj o tzw. inteligentnym projekcie, który miał za zadanie „oddać Bogu na wyłączność” kwestię stworzenia. Nie jest to właściwa droga. Spycha ona bowiem katolików do roli, jaką już kiedyś pełnili - a mianowicie zwolenników zabobonów. Sami autorzy zwracają uwagę na to, iż współczesna teologia nie może wiązać się z konkretnym obrazem świata, konkretnym „trendem” naukowym.

Ostatni rozdział, Żyć $w$ stworzonym wszechświecie, jest podsumowaniem całej książki. Myślę, że doskonałą konkluzją jest następujaccy fragment:

Człowiek, który ma świadomość, że ostatecznie pochodzi od Boga i żyje w świecie przez Niego stworzonym, znajduje się w innej sytuacji egzystencjalnej niż człowiek, który takiej świadomości nie ma lub ja wyklucza. Zasadnicza różnica pomiędzy tymi dwiema sytuacjami polega na odmiennym stosunku do dobra i zła. Zarówno człowiek uznajacy prawdę o stworzeniu, jak i człowiek, który jej nie uznaje, może zdobywać się na heroiczne czyny i popełniać najgorsze zbrodnie. Ale tylko

4 Wyrok na Galileusza i inne mity o nauce $i$ religii, red. R. L. Numbers, tłum. M. Romanek, Warszawa 2010, s. 161-169. 
człowiek ustawiający się w relacji stworzenia do Stwórcy ma świadomość tego, że różnica między dobrem i złem jest zakodowana w najgłębszych pokładach aktu stwórczego ${ }^{5}$.

Na końcu książki Poczatek $i$ stworzenie wszechświata znajduje się także dodatek, który jest skierowany do katechetów, przekazujących na swoich lekcjach naukę o stworzeniu.

Moim zdaniem czytelnikiem niniejszej książki może być każdy. Niekoniecznie musi to być teolog czy filozof, ponieważ jest ona napisana naprawdę przejrzyście, przez co nie ma problemów z jej zrozumieniem. Zawiera ona także wyjaśnienia podstawowych terminów filozoficznych, dzięki czemu każdy może poczuć się jak znawca tematu stworzenia. Każdy, kto bierze do ręki tę książkę, staje się poniekąd teologiem, szukającym odpowiedzi na nurtujące go pytania.

Olbrzymią zaletą książki jest to, że autorzy nie narzucają czytelnikom swojego zdania. Nie dokonuja także zbyt radykalnej oceny tych, którzy w ciagu wieków pobłądzili - czy to w sferze teologicznej, czy tė̇ naukowej. Pozycja wydana przez Copernicus Center Press jest godna polecenia wszystkim, którzy mają jakiekolwiek wątpliwości dotyczące stworzenia świata, znajdujące się na pograniczu nauki i teologii. Autorzy podają także szeroką listę odniesień do innych naukowców zajmujących się tą tematyką. Sięgając po tę książkę, nie zawiodłam się - podobnie jak inne pozycje napisane przez ks. Hellera i ta jest książką wysokich lotów.

5 M. Heller, T. Pabjan, Stworzenie i poczatek wszechświata, dz. cyt., s. 145-146. 